\title{
Selected Lyrics of Bontok's "Antoway, Ayoweng, and Chag-Ay" Songs: An Initial Stylistic Assessment
}

\author{
Jonnelle D. Fagsao \\ Mountain Province State Polytechnic College, Bontoc, Mountain Province 2616, Philippines; \\ jonnellefagsao@gmail.com
}

Received: 3 June 2019; Accepted: 24 July 2019; Published: 26 July 2019

\begin{abstract}
Most of the studies of Bontok songs in Bontoc, Mountain Province, Philippines have focused on the need to preserve an aspect of the "Ifuntok" (people of Bontoc) society, but the major aim of this paper first proposes an understanding of the Tokwifi's "Antoway", Bacwaden's "Ayyoweng", and Khensay's "Chag-ay", commonly regarded as songs of the Bontoks during wakes and funerals, taking into consideration its intrinsic potential on literary themes and musicality. This paper then organizes the framework of Prototype and Relevance Theory and applies it to the selected songs found in the three collections. It attempts to express how prototype and relevance theory can improve not only a thematic analysis of the selected songs, but also the extra-textual interpretations that can be drawn from them. In doing so, it adds to the contemporary thoughtful understanding of Bontok indigenous tradition, as they are deceptively eliminated of the impression of the past, recontextualized in today's literature and music curriculum, and associated in contemporary free issues and concerns in the Bontok community.
\end{abstract}

Keywords: antoway; ayyoweng; bontoc; mountain province; bontok; chag-ay; ifuntok songs; lufun; prototype theory and relevance theory

\section{Introduction}

Does Bontoc, Mountain Province have her own songs which bears the stamp of the Bontoks' cultural character? Do the Bontoks have indigenous songs, songs which when heard makes them feel that it is a component of their existence, belonging to their heart and soul, faithful in its revelation to their sentiments and ideals?

To this question, undoubtedly, the answer would be: they have, in much the same way that they have language, customs, traditions, and natural aspirations.

Bontoc, Mountain Province (see Figure 1) is located in the Cordillera Administrative Region (CAR) mountain range in the Northern Philippines [1]. The municipality is endowed with a wealth of melodies solely by nature, by origin, and by affinity. Locally, it is abound with folk tunes that lie scattered throughout the verdant mountains and fields, as mentioned by a galaxy of musicians like Bacwaden and Khensay whose creative works delineate the green pastures of life around the municipality and, in their massive textual compositions written in a local vernacular, the different nuances of the Ifuntok sentiment.

Today, one of the major tenets of the philology of the vernacular, as mentioned by [2], is its being text-centred, meaning; that the primary unit of analysis in the philological approach is the "text" which is crafted, bounded, internally cohesive, and coherently stretched discourse. The materials that are usually rendered in their textual forms are discursive forms, such as songs that are usually sung during wakes and funerals. The results are quite often experimental in nature, aside from the fact that their styles are drawn along Western frame of thought. 
There are countless numbers of songs in the collections, and to give example of each kind would take too long a time. Accordingly, this paper only centres on some exclusive selected songs from the collections of Tokwifi Group, Bacwaden, and Khensay from Bontoc, Mountain Province. The songs are categorized, evaluated, and interpreted anchored in the theories of [3,4], as well as textual analysis/rhetorical criticism and formal criticism/thematic analysis in order to draw out the study's main focus on stylistic features as well as their simple notations for purposes of determining their suitability or entry point as classroom instructional materials in teaching literature and music in today's twenty-first century curriculum.

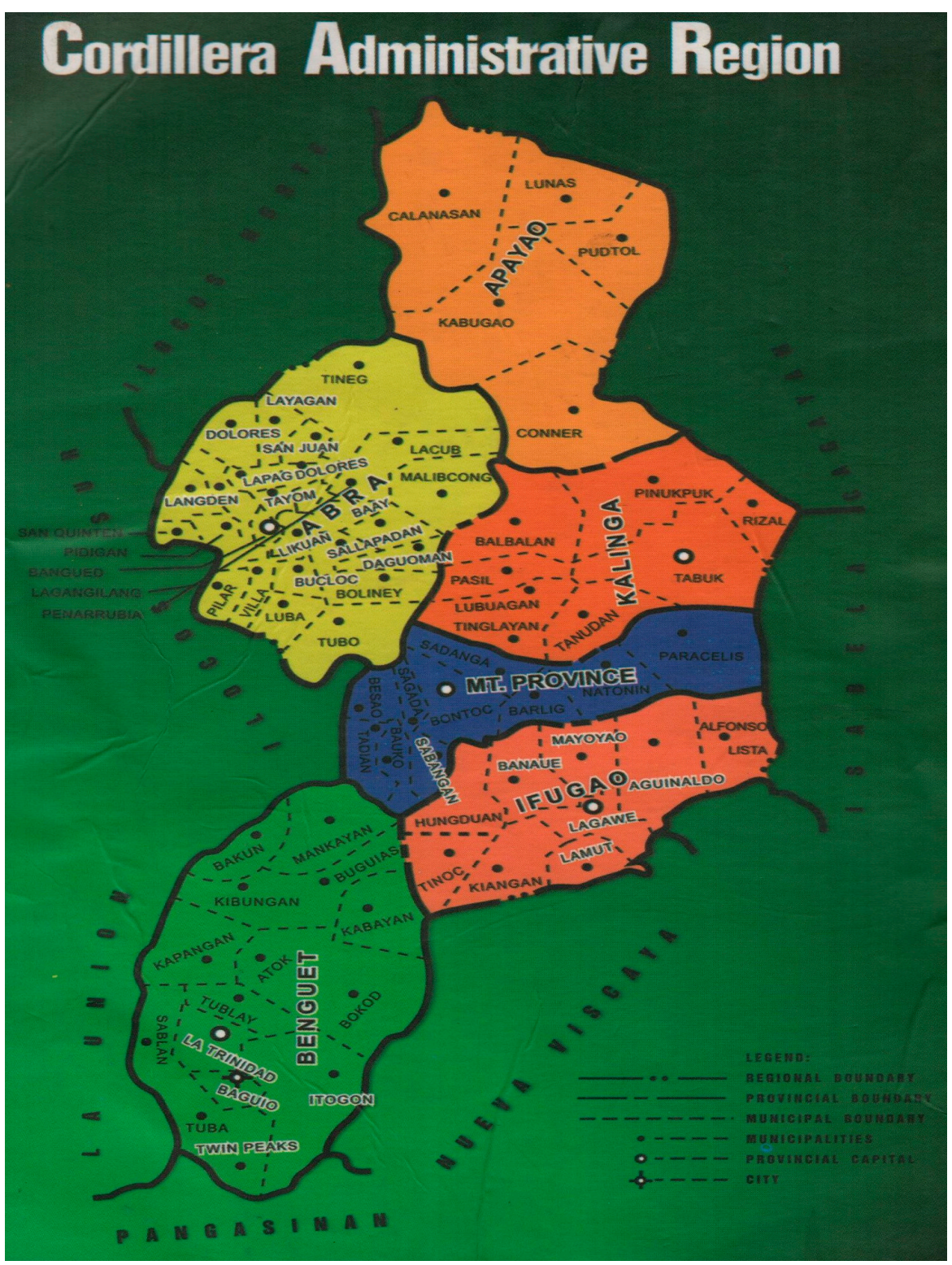

(a)

Figure 1. Cont. 


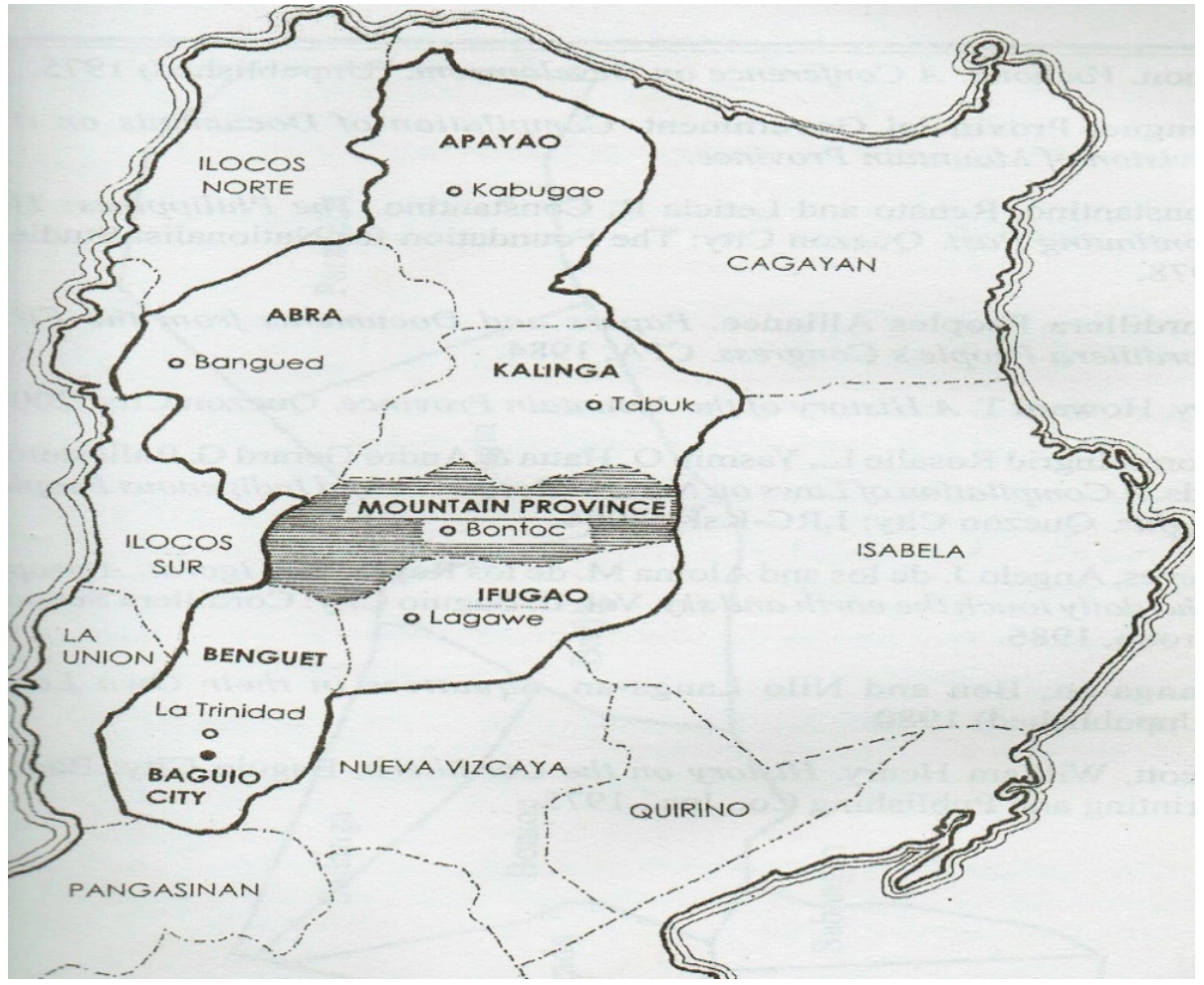

(b)

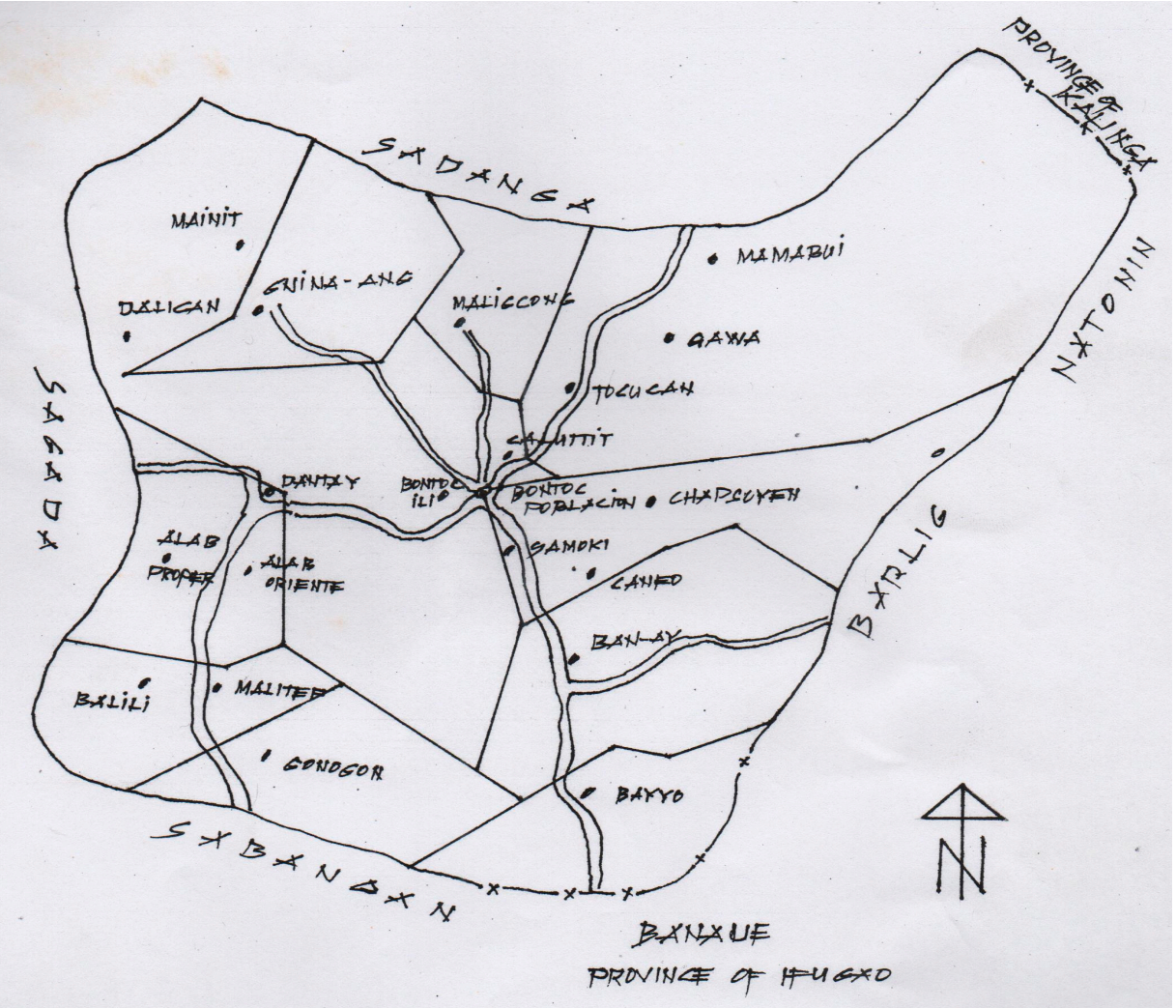

(c)

Figure 1. (a) Map of the Cordillera Administrative Region (CAR) (Photo by the researcher, 10 June 2019 (b) Map of Mountain Province as part of the Cordillera Administrative Region. (Drawing credit to Mr. Victor Ananayo, January 2010). (c) Map of Bontoc municipality in Mountain Province (Drawing credit to Ms. Jonah Gawidan, March 2018). 


\subsection{Bontok Indigenous Songs}

A complete understanding of the part that Bontok indigenous songs play in a people's literature requires a brief and general discussion of the literature as a whole. In examining the history of Bontok tribe's literature in the Northern hinterland of the Philippines, there are local composers who have contributed unique lyrics acted as a solid mechanism offering hopefulness in miserable situations and also influence in helpless lives. Hence, some Bontok tribe's songs become important constituents of mass media to transport the intended message to the audience, combined with the thought-provoking storyline. It is gratifying to note that the Bontok tribe can count a good number of highly regarded local composers whose songs were revived, polished, and in some cases modernized forgotten Western melodies. The Antoway, the Ayoweng, and the Chag-ay isnan Achug (Songs for the Dead) of the Bontoks made a mark of prominence in the arena of Bontok indigenous poetry and they are important part of indigenous writing that possessed sharp aesthetic sensibility. When considering that most songs are merely for entertainment, but there are potential associations, meanings, and crucial roles of communication in the society upon analyzing the lyrics intensely, as mentioned by [5], like roles in the culture of the Bontok tribe, in that it is through the song texts that the people are able to present their plights or sentiments without fear or favor. In consonance, [6] states that songs grant people of Bontoc, Mountain Province the opportunity to share their ingenious skill, and also use them as an avenue for the expression of their sentiments.

Songs according to [7] serve as a therapy to emotional problems; thus, like in the Bontoc communities, the songs were composed based on such circumstances to be rendered during wakes and funerals. As cited in [6], there are four (4) important elements suggested that tend to influence the human response to grief inducement: (a) the significance of the mode of death, (b) the social meaning of death, (c) the relationship between the deceased and the survivors, and lastly (d) the nature of the support network that is available to the bereaved.

In the culture of the Bontok tribe, every Bontok lineage members experience sequences of ceremonies from confinement all the way to death, which bind all locals both spiritually and culturally in their various groups. Subsequently, death cannot be disconnected from the existing, and also there is the conviction that, there is life after death, the Bontok tribe has established a structure of ceremonials to soothe the agony the mourning family feels, and also to establish a good bound for the deceased into the ethereal world of their ancestors. In support for the understanding of the word "tribe", Saboy's [8] explanation of the term is borrowed, as a result, he remarked:

"Tribe" is understood as interchangeable with the terms "ethnolinguistic group" and "ethnic group". I am aware of the colonial baggage that the word "tribe" bears and the notion of the philistine attached to it, notwithstanding the claim that contemporary anthropologists do not associate the term tribal society with anything negative. I also understood that "tribe" is quite problematic when one takes into account the general definition of the term by cultural anthropologists. (p. 60)

Over the years, wake and funeral songs in every Bontok communities have gone through extreme modifications. These modifications have come around due to Western influences that made the Bontok indigenes to interlace their compositions with Western tunes contributed to the social development of their community. To date, the preference of Western adaptations run in the veins of many local music enthusiasts and they are noticeable in the Antoway (sing), Ayyoweng (melody), and Chag-ay isnan Achug (songs for the dead) books.

As such, the Antoway songs that were collected from the Tokwifi (star) group; Bacwaden's Ayoweng songs; and, Khensay's Chag-ay isnan Achog, used a lot of stylistic features at different functions. Just like other songs from the neighboring tribes of Mountain Province, the Bontoks consider the ability of using varieties of stylistics in composing and presenting their songs as a mark of excellence in their vernacular language, as mentioned by [9]. Some of the songs were local translations liberally adapted from those of Western gospel songs. However, despite the format and formulaic verses, the songs reflect a different worldview while using slightly diverse tropes (figures of speech). 
The songs are rooted in the history, culture, and the traditions of the Ifuntoks. They are composed with carefully selected words, phrases, or sentences to create powerful and soothing effects that are usually sung at almost during "achug" (wakes) and "lufun" (funerals/burials), because the songs enable relations and close associates of the deceased to convey feelings and messages that may be difficult to express in words.

\subsection{Bontok Indigenous Identity in the Songs}

It is absolutely understood that songs are considered to be literary compositions that have musical notations. As a literary piece, the songs' lyrics have to be analyzed and interpreted according to the way that stylistic features were written, specifically in the choice of words (language) that reflect actual and implied conditions of the society from which they have emanated. In connection to this, I can cite [10] who mentioned that:

In such songs where the Igorots use their own language, they construct who they are and what they have become using mostly American folk, rock and country melodies; they tell stories of how they are making sense in their experiences in an unevenly globalizing, runaway world. (p. 109)

Of all the arts, literature is the only one that uses language as a medium that could be either written or oral. The medium of literature is language and language is a product of the society and it did not exist prior to the experience of human society. It developed when people saw the need to adopt a means by which they could communicate with each other through meaningful sounds-through songs. Consequently, songs are social creations that are products of society represented by symbolisms for literary themes and substances and the folks use them to interconnect with each other.

An interesting observation on the impetus regarding Bontoks' songs is found in another publication by Sofia Bacwaden on her work with Rev. Daniel P. Carino, and it is shown in Figure 2. The figure shows that the collection of Antoway, Ayyoweng, and Chag-ay songs are derived from two suggested major genres. The "Sinangad-om/Adkasin" (traditional/original) Bontok songs, which comprise the songs of the Bontoks ethnic group. Some songs (the traditional or ethnic), which were simple in structure and considered "old fashioned", were enhanced while using Western melody, creating a more modern style.

Secondly, the "Adwani" (contemporary) western musical influences that comprised translated gospel songs into Bontok dialect were introduced. Initially, some kinds of Western popular music were adopted to perform for Bontok audiences, including country western songs and ballads. The Bontoks tend to favour any music that can be combined with the traditional style of Bontok music. The composers of the collection of songs not only adopted some melodies, but also altered some western music to fit the taste of the Ifuntok audiences.

To date, the collected songs from Bontoks Antoway [11], Ayyoweng [12], and Chag-ay isnan Achog [13] are representations of Bontok's societal concern that primarily fuse Bontok melodic patterns and foreign tunes where the themes are delimited on Ifuntoks' spirituality, love and relationships, and lamentations.

Generally, the songs are religious and educational, and sung by any group in the Bontok community during wakes and funerals. Felix Khensay's Chag-ay Isnan Achog (see Figure 3) carries his identity on lyrics, melody, and rhythm that makes his songs a more vital spiritual power in all Bontoks' lives. Bacwaden's Ayoweng (see Figure 4) is a collection of her resultant musical expressions that is often used by the Ifuntoks during wakes and funerals, which are certainly worthy of every person's consideration. The Tokwifi's Antoway (see Figure 5) collection of songs are distinctive reflections of the Ifuntok's culture and traditions. With these songs popularly sung by the locals, they gained cultural luster, embraced wider horizons, and climbed to loftier spiritual dimensions. 


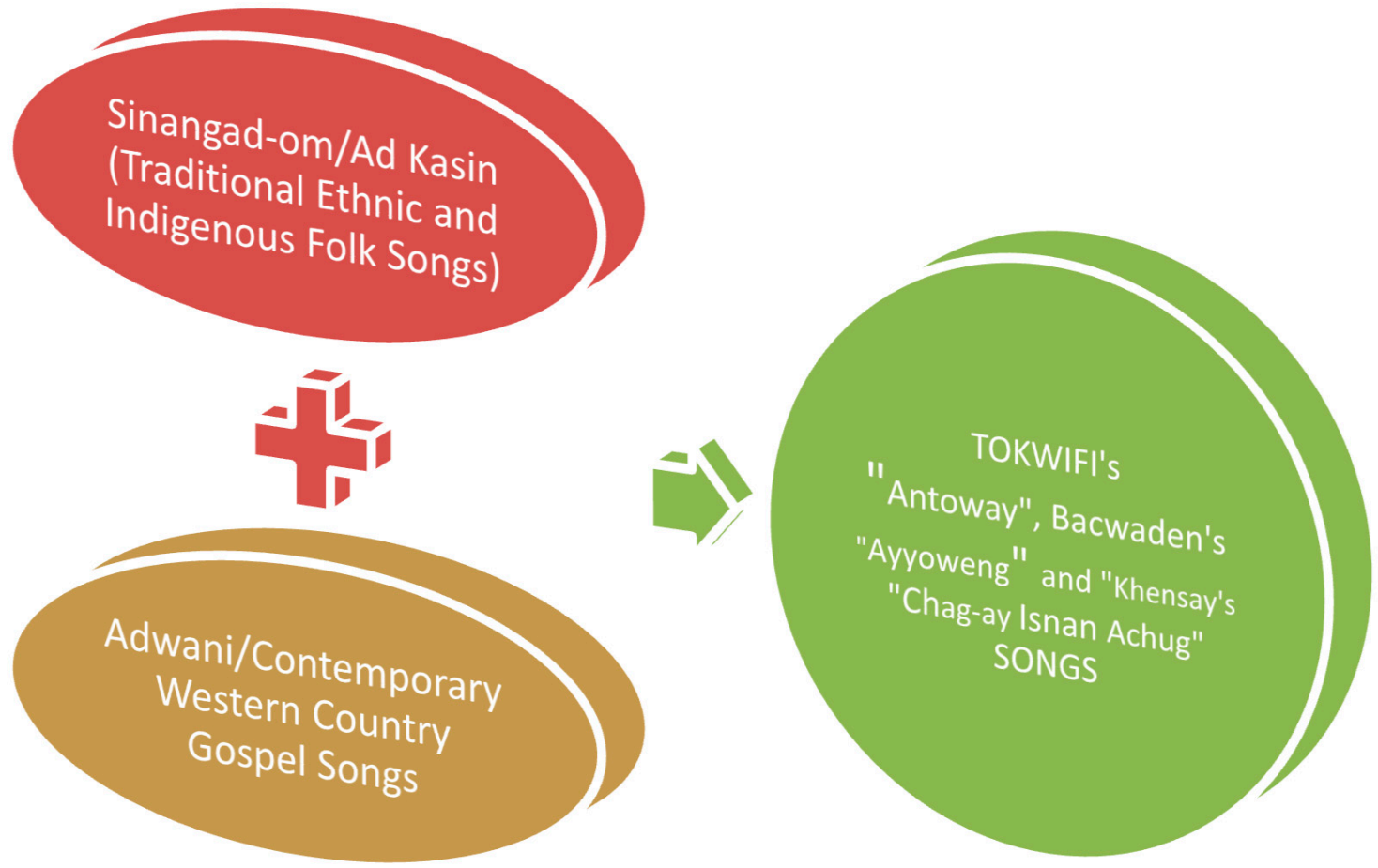

Figure 2. Lineages of Bontok Songs.

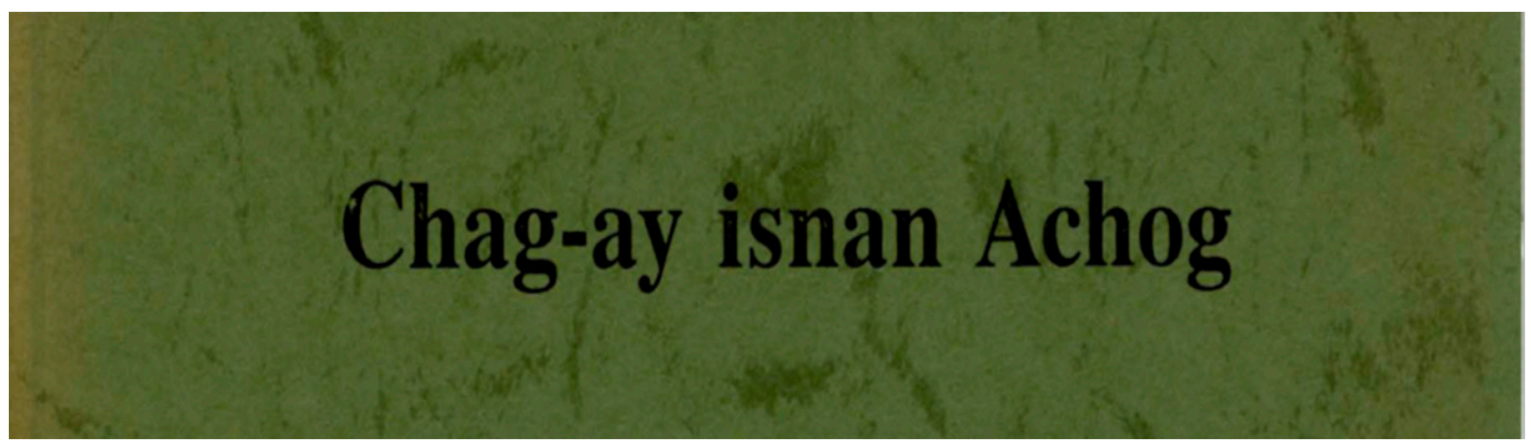

Figure 3. The cover page of Khensay's “Chag-ay Isnan Achug" by Bontoc Scriptures Society, 1992 (photo by the researcher, 12 January 2018).

Therefore, this paper then studies the utilization of Prototype and Relevance Theory and other literary approaches in the selected songs from the three collections. It critically analyzes the selected songs, while taking their cultural contexts gathered from researches and interviews with a few contemporary Bontok locals into consideration. I also significantly focused on the applications of some recent theories in language and perception to musical experiences in classroom circumstances. Through this study, I sought to magnify the understanding of musical cognition and how literature and music teachers, as well as students, think and verbally construct musical meaning, as reflected by the features of style focusing on tropes and schemes affecting the interpretation of the Bontoks' Antoway, Ayyoweng, and Chag-ay isnan Achug in the classroom. These songs, having distinctive figurative characteristics, speak of Bontok identity, which hopefully is still be melted into the background of a Philippine Cordilleran society, particularly on their thoughts and feelings on religion, family, and friendship. 


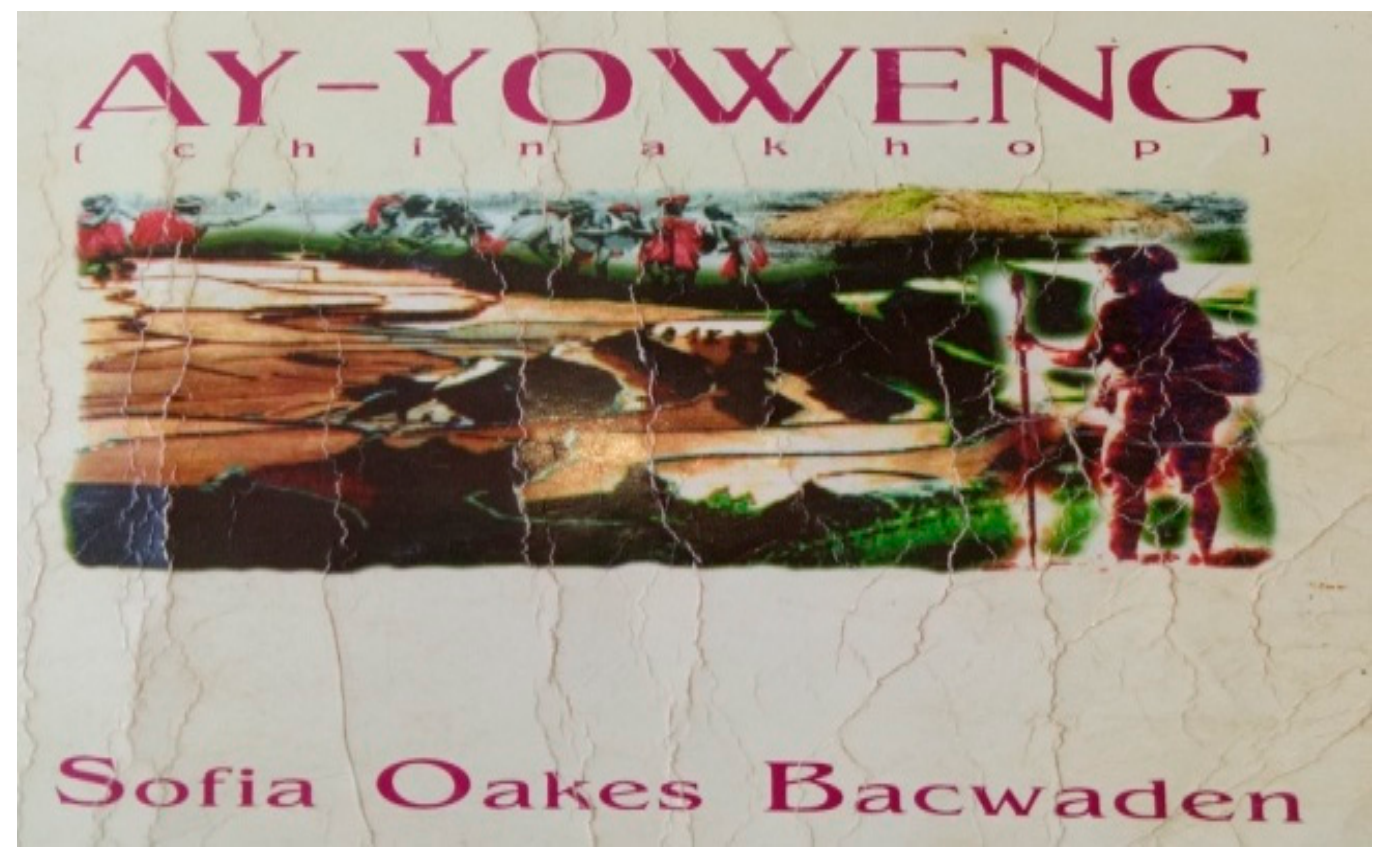

Figure 4. The cover page of Bacwaden's "Ayoweng" (2004) with a sketch of Bontok's culture as its background (photo by the researcher, 12 January 2018).

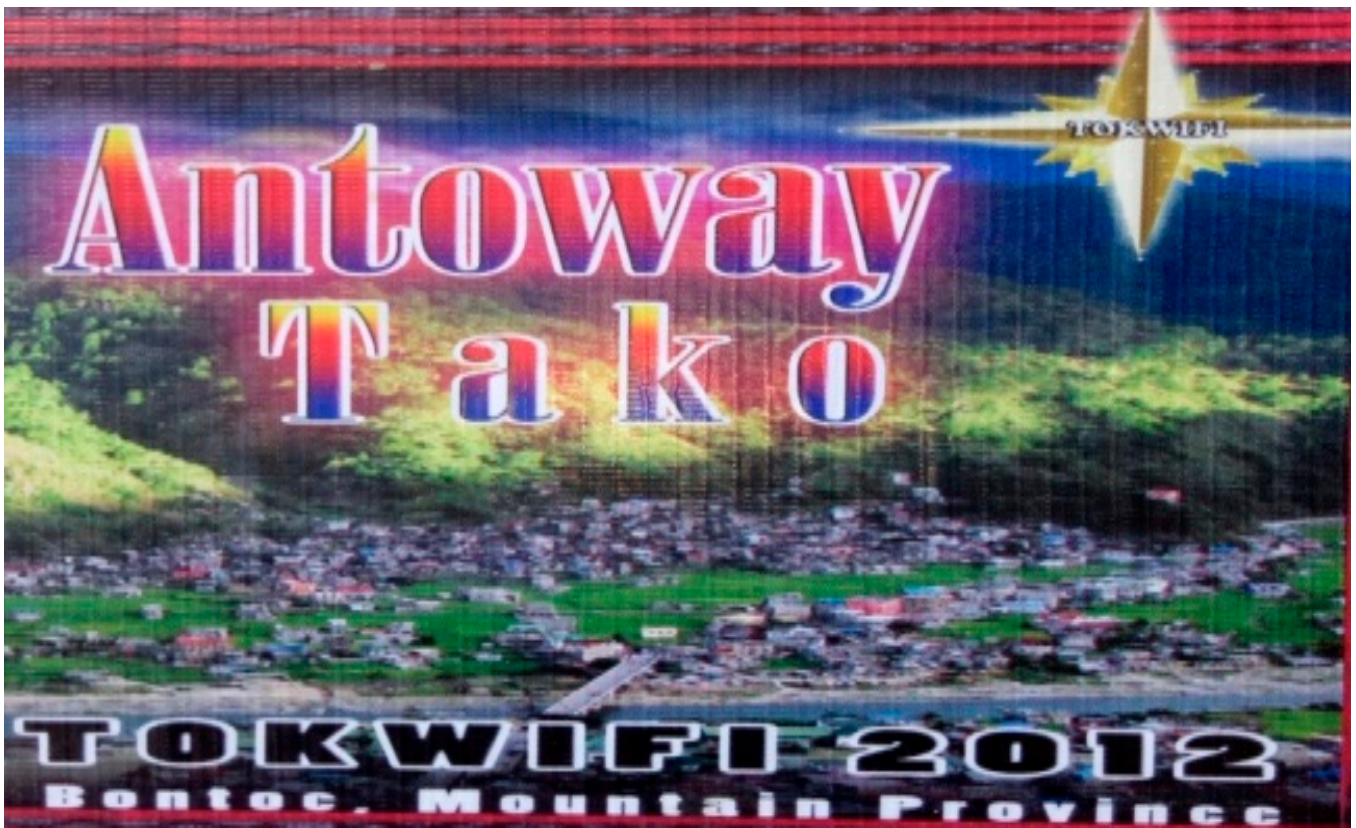

Figure 5. The cover page of Tokwifi's "Antoway" (2012) where the village of "Samoki" is its background (photo by the researcher, 12 January 2018).

\subsection{Bontok Songs in the Music Classroom}

Generally known to be a music-loving tribe, the Ifuntoks are naturally gifted with a gracious sense of rhythm and a good ear for music. With a reputation as lighthearted and pleasure-loving locals, they easily break out into songs at the drop of a hat. Musical life in Mountain Province, Philippines, is spread all the way throughout the year and it is practiced at work and at play, in love and in hate, in joy and in sorrow, in victory and in defeat, in worship and in contemplation of nature for every phase of life, even in times of bereavement. With this, I followed [14] who wrote: 
Group responsorial singing is found throughout the province, and is especially remarkable in Bontoc, Mountain Province where massive singing by men and women in pulsating rhythm creates special effects that generate enthusiasm among the participants as well as among the hearers. ( $p .47)$

As observed by [15], there are types of discourses in the music classroom that are useful and meaningful to students, and classifying these meaningful and useful languages into connotative and denotative. The former is rich, metaphoric, subjective, and expressive. The latter is technical, objective, and often abstract and cold. Language plays a key role in the music and literature classroom. A review of literature on music and literature teaching styles by [16] stated that one-third to one-half of music instructional time, as documented in the reviewed studies, involves a verbal component. Subsequently, that instructional time is voiced out, [16] soundly assert that the role language plays in the music classroom should be examined where:

The language connection is very much important in developing the quality of a musical experience. This should rather be explored. Only then can we hope to identify and develop those forces that contribute to our feeling moved when we experience music. Language is the essential tool that allows us to conceptualize and think about, to analyse and teach about these vital musical matters that ultimately can take us beyond words. (p. 37)

The use of this language is a gap into the learner-teacher's window of culture. There must be an awareness of the distinct discourses that the learners must acquire from their effective teachers to be successful in the classroom in order to be operative in a music classroom situation. Several researchers have examined and explored the importance of marking vocabulary to heighten concept formation on music that also includes the importance of students' personal vocabularies when describing musical perceptions, as other educators recognized. By focusing on the forms of language, such as the rhetorical and figurative ones, awareness into how significant and important music is was built and improved while using non-technical terms and formations.

With this, I found myself drawn to topics and work that were related to my background in language and music. I sought to find out more about how I learn and teach both language and music. I was intrigued with the theories of [2], who considered language to be a set of signs and symbols-a tool that mediates and changes people's inner environments. When the time came to choose an academic research topic, I sensed an opportunity for the intellectual exercise of merging two ongoing components of language and music in my life.

This study is also a response to the call for regional literature as evidenced by publications of folklore anthologies so that songs could be included in the literature of the Cordillera Region, which is now considered a must subject in the new curriculum in the Philippines. Besides, some of the Ifuntok's songs, in the advent of technologies, are nearing its extinction, so collecting and salvaging its little known, and vanishing culture is extremely important.

It would be wise and well for these songs to be included in the music classrooms to continue tapping the fountains of the Bontok's bottomless cultural heritage for fresh ideas and inspirations, so that learners may someday contribute to the great music in projecting aesthetic beauty, the charm, and the power of Bontok's indigenous music.

\subsection{The Role of Bontok Indigenous Lyrics in Songs}

In my quest to classify the role of Bontok tribe's traditional music, the lyrics of the selected songs keep on communicating human performance through the role of music in Bontoc. The song's texts are profound sources to appreciate human behaviour in association with music and they are expressions that are essential part of music. There are clear indications that the language that is used in relation with music differs from that of a normal discourse. The handling of Bontok songs as a form of speech expressions occur not only from musical considerate or from perception of the similar features of speech and music, but rather it is motivated by the importance of the songs of oral communication. 
In addition, it is a means for creative verbal expression that can replicate both personal and social experiences. However, from [7] conclusions, she added that:

The themes of songs have a tendency to centre space on procedures and matters of common importance and concerns to the social group or members of a community. They may deal with the traditions, everyday life or beliefs and customs of the society. This is accurate not only of serious songs connected with anniversaries and rites, but even of easy tunes like lullaby songs sung to children who have no recognition of their mother tongue enough to understand the meaning of the texts.

Music is interconnected with language, where speech melody places a certain models of sound behind some extent in music that is appreciated by the listener. The use of figurative language used in the selected songs reflect who the Bontok tribes are in a community where they belong to.

Looking critically at the Chag-ay isnan Achug by Felix Khensay [13], one can wrap up some indications in the song texts regarding the traditional life in the Bontok community. However, on Bacwaden's collection [12] of Ayoweng songs and Tokwifi's [11] Antoway songs, they aim to praise, entertain, inform, exhort, and inspire others about spiritual expressions that are directly or indirectly based from the Biblical texts.

\section{Methods}

\subsection{The Relevance Theory (RT)}

As [3] explained that RT aims at the interpretation of utterances and it checks on how the listener interprets the message from the speaker, that the human condition is geared towards maximization of relevance. They also observed and claimed that to understand an utterance, the listener should infer the intention of the speaker. Building on [3] theory, principles, such as Cognitive Principle of Relevance (CogPR) and Communicative Principle of Relevance (ComPR), associate the socio-cultural background in which the songs were set. Accordingly, from [3], this assumes that CogPR is a human condition that is projected to get the most out of the significance. The principle advocates that any speaker should struggle to make the utterance relevant enough to guarantee processing by the speaker. Therefore, when the songs are drawn from immediate environment, with attention to highlighting the community's concern, the listener in the same context will process the information.

Moreover, [3] expressed that ComPR, on the other hand, "assumes that utterances create expectations of optimal relevance". This principle has views which are relevant to this study explaining how the listener interprets the message of the Bontoks' songs depending on the composer's way of presenting his or her ideas in which it has links on this paper's aim at identifying and analyzing such features of views used by the composers and these are: (a) all utterances have various interpretations depending on coding meaning; (b) the interpretations fit the listener depending on occasions at the time of utterance; and, (c) listeners have the ability to interpret the speaker's message and they can either accept or reject depending on how the message is communicated.

However, ComPR is reduced in explaining how the features of style in Bontok songs can be compared anchoring in the use of [4] Prototype Theory.

\subsection{The Prototype Theory}

It is in its appealing of a contextual practice that relevance theory finds connection to the concept of Prototype Theory, which deals with the ranking of elements according to the frequency of occurrence. Therefore, stylistic features that most frequently occur are ranked on top, hence becoming most prominent. Applied to this paper, it seeks to scrutinize the stylistic features in the selected songs and ascertain the prototype features of style. The features of style may vary from one artist to another, depending on the message conveyed. This is the reason that explains why Relevance Theory comes in to capture the encoding and decoding of the information conveyed by the composers in communicating the message to the society through their prominent stylistic features in the selected songs. For that reason, both theories are applicable in meeting the objectives of this study. 


\subsection{The Stylistic Features}

There are many possible stylistic features that are used in songs, particularly in the forms of tropes, especially repetitions, similes, idioms, rhetorical questions, symbolisms, imageries, metonymy, code switching, neologism, allegory, and synecdoche will be considered if they are helpful in defining categories, relationships, and links to the musical experience and schemes, especially the literary repetitions. In the contemporary view, the forms of tropes and schemes involve the same kinds of linguistic and pragmatic operations that are used for ordinary, literal language.

In seeing the stylistic features that were used by the composers, readers can recognize them from schemes of construction in which the words are used in their meanings, but in which the sequences are of a distinctive pattern; and also recognize them from the tropes in which the ordinary relationships of meanings are altered.

In the selected songs, I preferred to use the metaphorical words that were written in rich Bontok vernacular language to dress the content of the tribe's speech, idea, or thought, which are situational and context bound. The tropes that were used in the songs were employed as a medium of expressions of thoughts, feelings, and ideas implicitly rather than explicitly. These techniques of language use, which can rightly be called tropes according to [17-22]; include metaphors, similes, idioms, analogies, hyperbole, metonymy, oxymoron, irony, and so on, which are applied in the collection of the selected songs. However, [23] classified the features of style as tropes and schemes that include the rhythm, word order, and they have nothing to do with meaning in the discourse. Tropes are the exodus or defilement of the linguistic code, providing related variations on the significance of an anticipated message in the discourse, depending how it has been used in a specific perspective.

In this study, I used trope or figurative language to encompass all of the above terms, but not on the schemes. In another work, [24] also proposes an appropriate characterization of trope, which is a "fundamental process by which one will able to think new things, an activity during which two (or possibly more) conceptual domains intersect, often unexpectedly and with novel consequences" (p. 31).

Finally, I provided a song code table for easy rechecking on the prominent features of styles that are anchored in the theories of $[3,4]$

The following song codes are shown in Table 1 below.

Table 1. Code numbers of the selected songs

\begin{tabular}{|c|c|c|}
\hline Code No. & Title of the Song & Book Title \\
\hline 1 & $\begin{array}{l}\text { Nan Layad Ensikhafan } \\
\text { Love can wrench a pain so deep }\end{array}$ & Ayyoweng \\
\hline 2 & $\begin{array}{l}\text { Adik taytaynan Sik-a } \\
\text { I'll Never Leave You }\end{array}$ & Ayyoweng \\
\hline 3 & $\begin{array}{l}\text { Nan Talna ay narpo ken Chios Apo } \\
\text { The Peace that my Saviour Has Given }\end{array}$ & Ayyoweng \\
\hline 4 & $\begin{array}{l}\text { Iyayoweng. Mi } \\
\text { We Will Sing }\end{array}$ & Ayyoweng \\
\hline 5 & $\begin{array}{l}\text { Manakabfalin. } \\
\text { How Great Thou Art }\end{array}$ & Ayyoweng \\
\hline 6 & $\begin{array}{l}\text { Ayke ka Apa-an ay Aped Tumay-nan } \\
\text { Are You Going Away with No Words of Farewell }\end{array}$ & Tokwifi \\
\hline 7 & $\begin{array}{l}\text { Nalagsak nan Am-in Mo Omchan Nan layad } \\
\text { When Love Shines In }\end{array}$ & Tokwifi \\
\hline 8 & $\begin{array}{l}\text { Mo Omchan nan Pachong } \\
\text { When the Time Comes }\end{array}$ & Tokwifi \\
\hline 9 & $\begin{array}{l}\text { Nan Kasasa-ad Taku Id kasin } \\
\text { Our Fate Before }\end{array}$ & Chag-ay \\
\hline
\end{tabular}


Table 1. Cont.

\begin{tabular}{ccc}
\hline Code No. & Title of the Song & Book Title \\
\hline 10 & $\begin{array}{c}\text { Nan Tet-ewa ay Ifaknang } \\
\text { The Truth of Riches }\end{array}$ & Chag-ay \\
\hline 11 & $\begin{array}{c}\text { Waday nan Esang ay Fab-alo } \\
\text { There was a Young Man }\end{array}$ & Ayyoweng \\
\hline
\end{tabular}

\section{Discussions}

\subsection{The Common Themes of the Selected Songs}

On the ceremonies, where the songs are directly related, I observed that the most prominent theme is the spirituality of the people of Bontoc, Mountain Province. The songs are replete with references to the Bible, its biblical characteristics, and its prosperity as a means to express the locals' deep-rooted thoughts and emotions. Another is based on love and relationships, as well as lamentation, which were written in the local language. I became interested in exploring the view that existed not only on the language through which every Bontok communicates, but a myriad of types of discourse within the same language, the Bontok way. I attempt to present the songs as musicultural phenomenon, one in which "music as sound" is intertwined with "music as culture", which Saboy [8] cited from [25]. With this considerable focus on the cultural context of the selected songs, I quote what [8] cited following Cross [26], who wrote:

Musics only make sense as musics if we can resonate with the histories, values, conventions, institutions, and technologies that enfold them: musics can only be approached through culturally situated acts of interpretation (p. 24).

\subsubsection{Spirituality}

Spirituality among the Ifuntoks is manifested in different ways, in different places and different times in accordance with its applicability in terms of specific ethnic beliefs, just like the other Igorot ethnic groups in the CAR.

In addition, [27] cited that the identifiable spirituality of the Igorots should be passed on. Spirituality, as practiced by the older generation of Igorots, is acknowledging the Supernatural Being or Creator with or without performing a ritual at any time yet, giving due respect to whatever religious affiliation he belongs to. The Creator is referred as God, the Almighty, the Powerful, the source of life, the Creator of all things termed in different local/ethnic names like "Kabunian/Lumawig" (Pagan god) to the Benguet Kankanaeys, "Alawagan" (God) to the Isnags, "Nintotongcho" (Almighty) to the Bontoks, "Adikaila" (Invisible) to the Western Kankanaeys, "Apo Dios" (Lord God), "Manakabalin" (Creator), etc. Being spiritual or believing in the value of spirituality redounds to respect of land, bodies of water, or the environment in general, which is anchored on the belief that a spirit or spiritual deity present in every living creature controls its life per se. The belief in the presence of spirits by the power of a Supernatural Being is a manifestation that there is God. Every Ifuntok's goal is to strive for better life, good health, etc. For this better life, they look up to a higher power for help in reaching their needs.

Spirituality has withstood the test of time. It is such an important part of the Bontoc people's lives. This has been proven by the fact that, throughout time, from the very beginning, there has been worship of some form, and it is still with the Ifuntoks today.

In the Christian faith, it was believed that God created the heavens and the earth. He created mankind to live on the earth with all other living creatures that are beneath the level of intelligence as the early Ifuntoks believed the same about Lumawig. To the Christian Igorots, they follow a book as a guide, and they communicate with him by prayer. Thus, these are reflected in the songs that were collected, which are used by any Ifuntok to pass across the message. To quote what one member of the singing group mentioned during an interview with her, she mentioned, "When we sing the 
songs, we communicate our concern and feelings to the people we are rendering our songs" (Bontoc, Mountain Province, February 2018). The text and the context within which some of the selected songs were sung clearly show that they are indeed Gospel songs that are meant to create an atmosphere of spiritual amity within the Bontok community.

\subsubsection{Love and Relationships}

This theme usually is common and is usually sung depending on the cause of death of the deceased. According to a member of the All Saints Cathedral Choir, explains that, love and relationship songs normally are well-known to all locals of a community. Sometimes, the songs may be sung for the living prominent or to the memory of a deceased person. In my 28 March 2018 interview with Bacwaden, the widely acknowledged Bontok composer and choral arranger of the book Ayoweng mentions that some of her compositions are purely on love and relationships, but not directly adapted from the Gospel (interview by the researcher, Bontoc, Mountain Province). She has her own "formula" that differs from other local composers. One of her songs "Layad Ensikhafan" (Love can wrench a pain so deep) (see Table 2) portrays a Bontok lad's continuing devotion to a Bontok maiden that he courted in an "ulug" (sleeping quarters of the teen-aged Bontok girls); even that love was lost, of which nothing is left but heartaches and memories is the most popular among her songs during wakes, because the melody is modified to the tune of "Love at Home", a popular Western melody.

Table 2. Layad Ensikhafan.

\begin{tabular}{cc}
\hline Words and Music by Christopher Oakes & Sofia Oakes Bacwaden \\
\hline Nan layad ensikhafan & Love can wrench a pain so deep \\
Tet ewa'y sikab & To the core 'twill creep \\
Layad ay nen likhatan & Love so beautiful, I weep \\
Nar-os tsat am in & All are past and gone \\
Seg-ang yangkay nan wad-ay & How can this our love be true? \\
Sika et achi mampay & End with grief as residue \\
Ya ngag kasin ta angnen & What else can we say or do \\
Nar-os tsat am-in & All is past and gone \\
Layad ta'y chachama & Love so sweet Love so deep \\
Ento pay kasin chichi & Where's the love we pledge to keep \\
Nar-os tsat am-in & All is past and gone \\
San en ta nen fowekhan & Hand in hand so full of love \\
Ad-im ngen sem-ken & Places we did rove \\
San enta nen fachangan & Memories are all we have \\
Nar os chat am in & All is past and gone \\
Tak en mo nen mowasan & All's not what it seems to be \\
Sumeg-ang ka man & Listen to my plea \\
Ta kasin ta lomanen & Love rekindled strong will be \\
San layad tay chwa & With you by my side \\
San layad ta'y chachama & Love we shared was strong and true \\
Wed wechas fangunen ta & Forged together ever new \\
Ta't ampay en among ta & Come let's pledge our love anew \\
Omafong ta'y chwa & Come and be my bride \\
\hline
\end{tabular}

This song, which is popularly sung by various local artists, is a love song that is preferably sung depicting a diasporic Bontok lad pouring out his sentiments yearning for his ladylove. Nan Layad en sikhafan, tet ewa'y sikab, shows the speaker values the love he offered to the ladylove that he truly admires. He is basically presenting that his love for her is physical, "tet ewa' $y$ sikab" (To the core "twill creep) within his soul, body, and mind. His agape love is figuratively mentioned and it ends with a wish for a better tomorrow "omafong ta'y chwa" (come and be my bride); but on the contrary, all of these being felt were gone because of death separated him from her.

Adding some explanations from Mrs. Sofia Bacwaden, and Mrs. Estella Felwa (interview by the researcher, Bontoc, Mountain Province, March 2018), they revealed that the song is intended for wakes, because of its profound lyrics related to death and separation. According to Mrs. Bacwaden, the support to the message of the last lines was found at the last two stanzas, where the singer wanted the 
listeners to be aware that what happened between the two personas can be reinforced by the message that they can again start anew and pledge for their love in the eyes of the people and of God. They confessed that:

"For if they will be joined together, then their love will be eternal that will go on forever even after death. For him, his love for her wife is his life, it is his breath. Loving her is like nature, it is like the air human beings all need to survive".

\subsubsection{Lamentation}

Lamentation can also be seen in the selected songs of Tokwifi of Samoki, which expresses mourning or grief. It is usually done when the deceased person is placed on the coffin for a final tribute before being taken to the grave. The songs' texts centred on the attributes of the deceased, reference to the families, and the background of the deceased. It also covers the range of the dead's social life, as well as; kinship, marital, and familial family members, and societal values of the dead.

At least three songs of lamentation by the Tokwifi can be identified from the selected songs, "Mo Omchan nan Pachong" (When the Time Comes), Ayke ka Apa-an ay Aped Tumay-nan (Are You Going Away with No Words of Farewell), and Nalagsak nan Am-in Mo Omchan Nan layad (When Love Shines In).

These songs can awaken those suppressed people to understand some assistance that is given to them to think positively. In the course of listening to the song's lyrics, there are lines in the refrain of the song, "Mo Omchan nan Pachong" (When the Time Comes) that encourage the bereaved persons to feel relieved from their sorrows, revealing that "death is not the greatest loss in life ... soon we will meet again someday". Hence, the song plays an emotional role, which affects people's life.

\subsection{Stylistic Analysis of the Selected Songs}

\subsubsection{The Classification of Tropes}

In this paper, I followed the conventional use of stylistic features, with a number of qualifications. I even stick to the natural notion of focusing on the figurative uses of language as contrasting with literal uses of the same lexical items in the same order. Although the main interest in researching tropes is that such uses feel intuitively different to literal uses, and an account of understanding in linguistic communication must concern it with such issues. There is a need to be more precise about which intuitions of language users in identifying figuratively-used expressions (tropes) are relevant. The use of frequency distribution tables was to analyse the features of style in the selected songs from the three references. Prototype Theory is the road map on which stylistic features are measured to find those that are prominent in the songs selected.

\section{Personification}

Personification is a statement that attributes human qualities to non-human entities, such as objects or animals. From the songs, the lyrics says, "Enayuweng et nan leng-ag ko", my soul sings or "Nan ayyuweng nan billit", the bird sings, for instance. Neither the soul nor the bird can do these things, but these personifications transport a particular idea clearly to the senses.

Table 3 shows this type of trope. 
Table 3. Examples of Personification.

\begin{tabular}{|c|c|c|c|}
\hline $\begin{array}{l}\text { Song } \\
\text { Code }\end{array}$ & Personification & L2 Translation & Frequency \\
\hline 1 & $\begin{array}{c}\text { Nan layad ensikhafan } \\
\text { San enta nen fuwekhan } \\
\text { Seg-ang yangkhay nan waday } \\
\text { Layad ta'y chachama } \\
\text { Ta kasin ta nomanen, san layad ta'y chuwa }\end{array}$ & $\begin{array}{l}\text { Love can wrench a pain so deep } \\
\text { Hand in hand so full of love } \\
\text { Fate has willed that it should be } \\
\text { Love is sweet } \\
\text { Love rekindled strong will be, } \\
\text { with you by my side }\end{array}$ & 5 \\
\hline 2 & Kanan nan pusok & My heart keeps saying & 1 \\
\hline 3 & Pakhawisena nan filig & All the hills adorning & 1 \\
\hline 5 & $\begin{array}{c}\text { Enayuweng et nan leng-ag ko } \\
\begin{array}{c}\text { Nan ayoweng nan billit. Ay madngek iska } \\
\text { khaew }\end{array}\end{array}$ & $\begin{array}{c}\text { Then sings my soul } \\
\text { I hear the birds } \\
\text { Sing sweetly in the trees }\end{array}$ & 2 \\
\hline 6 & Kaman foyag ket naawatak & $\begin{array}{c}\text { Every song in my heart lies a } \\
\text { burning }\end{array}$ & 1 \\
\hline \multirow[b]{2}{*}{7} & Sulwen ay enkalalag. Nan sanga en mayagyag & $\begin{array}{l}\text { Love will teach us how to pray } \\
\text { Love will drive the gloom away }\end{array}$ & \multirow[b]{2}{*}{2} \\
\hline & Puso en malagsakan. Mo layad omchan & $\begin{array}{l}\text { How the heart is turned to } \\
\text { singing } \\
\text { When love shines in }\end{array}$ & \\
\hline 8 & $\begin{array}{l}\text { No omchan nan pachong nan masisyanan, } \\
\text { sikhab nan manmekhan }\end{array}$ & $\begin{array}{l}\text { When the parting time brings it } \\
\text { sad refrain }\end{array}$ & 1 \\
\hline & TOTAL & & 13 \\
\hline
\end{tabular}

Metaphor

Most of our ordinary conceptual system is metaphorical in nature, which is suggested as a substitution of one thing with another. It is an indirect comparison where according to [28], it is a figure of speech in which something (A) is identified with something else (B) in order to attribute to A a quality that is associated with B. In order to know metaphorical language used in the songs, Table 4 shows how this stylistic feature is used to some of the songs in codes number two (2), four (4), eight (8), and 11 , respectively.

Table 4. Examples of Metaphor.

\begin{tabular}{|c|c|c|c|}
\hline $\begin{array}{l}\text { Song } \\
\text { Code }\end{array}$ & Metaphor & L2 Translation & Frequency \\
\hline 2 & Mo omchan nan timpo & And when you're old and gray dear & 1 \\
\hline 4 & $\begin{array}{c}\text { Mananynan mi isnan luta } \\
\text { Et masab-at taku ken Chios Ama }\end{array}$ & $\begin{array}{l}\text { Together, we will be one } \\
\text { With God in that far-off promised land }\end{array}$ & 1 \\
\hline \multirow{2}{*}{8} & $\begin{array}{l}\text { No waschin kinchang na fiyag } \\
\text { isnan luta }\end{array}$ & $\begin{array}{l}\text { Once we have crossed that line and } \\
\text { our life is done }\end{array}$ & \multirow{2}{*}{2} \\
\hline & $\begin{array}{l}\text { Ili ad chaya ay kakhakhawisan, } \\
\text { Am-in kachangyan }\end{array}$ & $\begin{array}{l}\text { In the city of heaven } \\
\text { Where all are blessed as one }\end{array}$ & \\
\hline \multirow{2}{*}{11} & Alike ta kumchang ta & Come and cross the river with me & \multirow{2}{*}{2} \\
\hline & Ali ka ta eniChulya ka & Come and be a Chulya-a & \\
\hline \multicolumn{3}{|c|}{ TOTAL } & 6 \\
\hline
\end{tabular}


Simile

Simile is widely recognized as a rhetorical figure, whereby an author uses a comparison between two dissimilar things [29].

From the texts subjected to analysis shown in Table 5 is the following examples of simile on the songs in codes three (3) and nine (9).

Table 5. Example so Simile.

\begin{tabular}{|c|c|c|c|}
\hline Song Code & Simile & L2 Translation & Frequency \\
\hline \multirow{12}{*}{3} & Kag fangfanglon si tupkaw & Like the fragrance of flowers & \multirow{12}{*}{12} \\
\hline & Kag lagyet isnan ekhew & Like the soft summer showers & \\
\hline & Kag wasi isnan talan-o & Like the dew of the morning & \\
\hline & Ka takchag si filig & As high as the mountain & \\
\hline & Ka cha-em si fayfay & As deep as the sea & \\
\hline & Kag sed-echem na'y umchan & Like the twilight comes stealing & \\
\hline & Kag pattong isnan maschem & Like an evening bell pealing & \\
\hline & Kag ayyeng ay enkhanges & Like a song sweet and tender & \\
\hline & Kag lifo-o'y enukhang & Like a cloud that is rifted & \\
\hline & Kag awit ay yumap-ew & Like a burden that is lifted & \\
\hline & Kag umpa isnan seg-ang & Like a rest after sorrow & \\
\hline & Kag lagsak isnan kawaksana & Like a jubilant morrow & \\
\hline \multirow[t]{2}{*}{9} & $\begin{array}{l}\text { Kag tako isnan cheycha takho's } \\
\text { fakinlolota a maid pammati cha } \\
\text { ken Apo ay Chios Ama }\end{array}$ & $\begin{array}{l}\text { We are like those fears who } \\
\text { don't believe in God }\end{array}$ & \multirow[t]{2}{*}{2} \\
\hline & Ad kasin et kag takho natey & $\begin{array}{l}\text { Before we are like } \\
\text { non-living things }\end{array}$ & \\
\hline & TOTAL & & 14 \\
\hline
\end{tabular}

\section{Rhetorical Questions}

With this, [30] says that it is basically a question not expecting an answer, or one in which the answer is more or less-evident. Table 6 shows examples of Rhetorical questions that are found mostly in the songs.

Table 6. Examples of Rhetorical Questions.

\begin{tabular}{|c|c|c|c|}
\hline Song Code & Rhetorical Questions & L2 Translation & Frequency \\
\hline 1 & Seg-ang yangkhay nan wad-ay? & How can this our love be true? & 1 \\
\hline 2 & Ya ngag kasin ta angnen? & What else can we say or do? & 1 \\
\hline 4 & Ngag nan chawaten mi'n sik-a? & We ask you this our plea? & 1 \\
\hline 6 & $\begin{array}{l}\text { Ayke ka apa-an ay aped tumaynan? } \\
\text { Mid ngen pa-at kalim si taynam? }\end{array}$ & $\begin{array}{l}\text { Are you going away with no words } \\
\quad \text { of farewell? } \\
\text { Will there be not a trace left behind? }\end{array}$ & 2 \\
\hline 7 & $\begin{array}{c}\text { Khawis negn am-in nan ilan mo } \\
\text { layad em igwa? }\end{array}$ & $\begin{array}{l}\text { How the world will grow with } \\
\text { beauty when love shines in? }\end{array}$ & 1 \\
\hline 10 & Sino nan egyaten tako? & Who we are afraid of? & 1 \\
\hline 11 & $\begin{array}{c}\text { Wad-ay ngen nuwang si pastolam? } \\
\text { Ya payew ay entuncham? }\end{array}$ & $\begin{array}{c}\text { Do you have carabaos aplenty? } \\
\text { And field so wide for me? }\end{array}$ & 2 \\
\hline \multicolumn{3}{|c|}{ TOTAL } & 9 \\
\hline
\end{tabular}


Neologism

Under this trope, [29] says that there is no vocabulary that is stable. Changes are inevitable. Therefore, neologism is a branch of linguistics that deals with word formation. Furthermore, [30] explains that Neologism is a new word or expression or a new meaning of a word. The word is used to refer to the various coinages of words with roots in English and other languages. This stylistic device is used due to a lack of equivalent word in the language being used. In some of the songs, many words have been borrowed. Examples of Neologism are shown in Table 7 on the song that is coded as number one (1), two (2), three (3), four (4), five (5), and six (6).

Table 7. Examples of Neologism.

\begin{tabular}{|c|c|c|c|}
\hline Song Code & Neologism & L2 Translation & Frequency \\
\hline 1 & $\begin{array}{c}\text { Tet-ewa'y (tet-ewa+ay) } \\
\text { Wed-wecha's (wed-wecha }+ \text { is) } \\
\text { Cha-chi (cha+tudi) } \\
\text { Ta't (ta+et) }\end{array}$ & $\begin{array}{c}\text { That is true (Blending) } \\
\text { Forged together (blending) } \\
\text { Those (blending) } \\
\text { In such a way (blending) }\end{array}$ & 3 \\
\hline 2 & Engkhana'y (enkhana+ay) & Until (blending) & 1 \\
\hline 3 & $\begin{array}{c}\text { Kag wasi 'snan talan-o (isnan) } \\
\text { Kag lifo-o'y (lifo-o+ay) }\end{array}$ & $\begin{array}{l}\text { Of (clipping) } \\
\text { Cloud (blending) }\end{array}$ & 2 \\
\hline 4 & $\begin{array}{c}T a^{\prime} y n a^{\prime} y(t a+a y)(n a+a y) \\
M i^{\prime} n(m i+k e n) \\
\text { Siya's (siya+is) }\end{array}$ & $\begin{array}{l}\text { Just (blending) } \\
\text { We (you) } \\
\text { This (clipping) }\end{array}$ & 3 \\
\hline 5 & $\begin{array}{c}\text { 'snan (is+nan) } \\
\text { Nan mula's (mula+as) } \\
\text { Nancheycha'y (nancheycha +ay) } \\
\text { Enkanta'n (enkanta }+ \text { nan) } \\
\text { Tetewa'y (tetewa+ay) }\end{array}$ & $\begin{array}{l}\text { Of (clipping) } \\
\text { Plants in (blending) } \\
\text { Those (blending) } \\
\text { Sing (blending) } \\
\text { Truly (blending) }\end{array}$ & 5 \\
\hline 6 & $\begin{array}{l}\text { Semek ko'y }(k o+a y) \\
\text { Tay mi'd (maid) } \\
\text { Ka't kagtuna }(\text { ka+et })\end{array}$ & $\begin{array}{l}\text { My (blending) } \\
\text { None (clipping) } \\
\text { You are (blending) }\end{array}$ & 3 \\
\hline & TOTAL & & 17 \\
\hline
\end{tabular}

Code-Switching and Code-Mixing

Code-Switching and Code-Mixing are the most important features and well-studied speech processes in multilingual communities. Definitions vary, but both utilized the term "code", which was adopted by linguists from the field of communication technology [31], referring to "a mechanism for the unambiguous transduction of signals between systems", analogous to what switching of language signifies a system that is used by bilingual speaker-hearer in everyday communication. Therefore, term "code" is frequently used nowadays by linguists as an "umbrella term for languages, dialects, styles etc" [32].

Further, term "switching" refers to the alternation between different varieties that are used by the bilingual/bidialectal during the conversational interaction. This phenomenon can be examined from various angles, but the important part of this study is to illustrate the conscious and unconscious patterns of such language behaviour and the motivation behind it. On the other hand, code-mixing refers to "embedding of various linguistic units, such as affixes (bound morphemes), words (unbound morphemes), phrases, and clauses. In order to infer what is intended, the participants must reconcile what they hear with what they understand, as cited by [32]. Examples of code-switching are shown in Table 8, where song code 11 is prominent. 
Table 8. Examples of Code-Switching and Code-Mixing.

\begin{tabular}{cccc}
\hline Song Code & $\begin{array}{c}\text { Code-Switching and } \\
\text { Code-Mixing }\end{array}$ & L2 Translation & Frequency \\
\hline 4 & Tay nay nen "abroad" $k a$ & Now that you are in God's company & 1 \\
\hline \multirow{4}{*}{ Ay en nananuman ad Agoyyo } & To water his fields in Agoyyo & \\
Inila nan a Ikidla-a & There he saw a Kidla-a & 4 \\
& Wad-ay ngen nuwang si pastolam? & Young man from Chulya, so free & Do you have carabaos aplenty? \\
TOTAL & & 5 \\
\hline
\end{tabular}

Imagery

Imagery involves the application of vivid description, which is rich in sensory words, in order to create pictures, or images, in the mind of the reader. Composing songs involves the description of persons, animals, and objects to create a mental picture in the mind of the reader, to create special feelings and evoke emotion. The use of imagery enables the singers of songs to achieve emotive descriptive effects through associating words with mental pictures or impressions. Imagery involves one or more of the five human senses. It can also refer to the "pictures" that are perceived with the mind's eyes, ears, nose, tongue, skin, and through which one experiences the invisible world that is created by poetic language.

Table 9 shows the examples of imagery.

Table 9. Examples of Imagery.

\begin{tabular}{cccc}
\hline Song Code & Imagery & L2 Translation & Frequency \\
\hline & Tupkaw & flowers & \\
Lagyet & showers & \\
Wasi & Dew & \\
Filig & hillside & \\
& Sed-e-chem & twilight & 10 \\
3 & Pattong isnan maschem & Evening bell & \\
& Akhew & Sunset & \\
Ayyeng & Song & \\
Lofo-o & Cloud & \\
Awit & Burden & \\
& Tukwifi & Stars & \\
Ka-ew & Trees & \\
& Mula's ka payew & Plants in the fields & \\
& Magmagkit & Young lass & \\
& Fab-alo & Young man & \\
& Payew & fields & \\
\hline
\end{tabular}

Hyperbole

Hyperbole is an exaggeration or over statement, which is usually deliberate and not meant to be taken literally [33].

Shown in Table 10 are examples of hyperbole in the song coded as one (1), four (4), five (5), and six (6). 
Table 10. Examples of Hyperbole.

\begin{tabular}{cccc}
\hline Song Code & Hyperbole & L2 Translation & Frequency \\
\hline 1 & Nan layad ensikhafan & Love can wrench a pain so deep & 1 \\
\hline 4 & $\begin{array}{c}\text { Tay nay et kinumchang } k a \\
\text { Kinchang mu san wanga }\end{array}$ & $\begin{array}{c}\text { Now that you have crossed death sea } \\
\text { You have crossed the wide river }\end{array}$ & 2 \\
\hline 5 & $\begin{array}{c}\text { Enwesawes san chakem ay luma-us } \\
\text { Ya nan kichu ay kumedya chadlus } \\
\text { Enayuweng, enkanta'n leng-ag ko }\end{array}$ & $\begin{array}{c}\text { I hear the rolling thunder } \\
\text { And feel the gentle breeze } \\
\text { Then sings my soul }\end{array}$ & 3 \\
\hline 6 & Kaman foyag ket naawatak & Every song in my heart lies aburning & 1 \\
\hline
\end{tabular}

\subsubsection{The Classification of Schemes}

\section{Repetition}

Some singers employ a lot of lexical or structural repetitions not to bore the audience or an indication of the lack of new ideas, but to create effects. Singers use repetition to gather momentum in order to bring a brighter idea in the next stanza, to emphasize a point, or to authenticate a claim. Through repetition, singers stir the emotions of the audience. Panegyric of the dead is always sung when performing at a funeral ceremony. The performing artist traces the deceased through his ancestors, enumerates their good deeds and achievements, and links it to those of the deceased.

Structural repetitions are the most featured in the texts subjected to analysis. One can distinguish between two kinds of repetitions: full repetition (repeating whole segment) and partial repetition (repeating a part of the segment). Tables 11 and 12 show examples of repetition that are found in the songs.

Table 11. Examples of Repetition.

\begin{tabular}{|c|c|c|c|}
\hline Song Code & Repetition & L2 Translation & Frequency \\
\hline 1 & Nar-os cha't am-in & $\begin{array}{c}\text { All is past and gone (repetition of } \\
\text { whole segment) }\end{array}$ & 4 \\
\hline 2 & Adiktaytaynan sik-a & $\begin{array}{l}\text { I'll never never leave you (repeating a } \\
\text { part or a segment) }\end{array}$ & 2 \\
\hline 3 & $\begin{array}{l}\text { Nan talna ay narpo ken } \\
\text { Chios Ama }\end{array}$ & $\begin{array}{l}\text { Is the peace that my Saviour has given } \\
\text { (repeating of whole segment) }\end{array}$ & 4 \\
\hline 7 & Layad omchan & $\begin{array}{l}\text { When love shines in (repeating a } \\
\text { part/segment) }\end{array}$ & 2 \\
\hline 8 & At waday & $\begin{array}{c}\text { There will be (Repeating a } \\
\text { part/segment) }\end{array}$ & 1 \\
\hline 11 & Ay, ay Salidummay & Ay, ay Salidummay (partial repetition) & 3 \\
\hline \multicolumn{3}{|c|}{ TOTAL } & 16 \\
\hline
\end{tabular}

Anaphora

Anaphoric repetition is called the repetition of a word or a phrase at the beginning of two or more consecutive sentences, which is often used in poetry that increases sound harmony of speech [34].

As a poetic figure, anaphora is used to describe the repetition of elements at the beginning of a poetic unit, where repeated actions begins and ends in every stanza [35]. Basing on [36], he describes that anaphora extends beyond the poetic line into formula, scene, and theme, because the repetition in a tradition creates anaphoric effects. 
Table 12. Examples of Anaphora.

\begin{tabular}{|c|c|c|c|}
\hline Song Code & Anaphora & L2 Translation & Frequency \\
\hline 1 & $\begin{array}{l}\text { Layad ta'y } \\
\text { Chachama }\end{array}$ & $\begin{array}{l}\text { Love so sweet } \\
\text { Love so deep }\end{array}$ & 1 \\
\hline 2 & $\begin{array}{l}\text { Et sik-a metla-eng } \\
\text { Nan enak laylaychen } \\
\text { Adik taytaynan sik-a }\end{array}$ & $\begin{array}{l}\text { I'll always be the same } \\
\text { I'll never never change } \\
\text { I'll never leave you }\end{array}$ & 1 \\
\hline \multirow{2}{*}{3} & $\begin{array}{l}\text { Talna narpo ken Chios Apo } \\
\text { Talna ay narpo ad tongcho }\end{array}$ & $\begin{array}{l}\text { Peace that my Savior has given } \\
\text { Peace that He sendeth from heaven }\end{array}$ & \multirow{2}{*}{2} \\
\hline & $\begin{array}{l}\text { Kag fangfanglun si tupkaw } \\
\text { Kag lagyet isnan ekhew }\end{array}$ & $\begin{array}{l}\text { Like the fragrance of flowers } \\
\text { Like the soft summer showers }\end{array}$ & \\
\hline 5 & $\begin{array}{l}\text { Tet-ewa'y manakabfalin ka } \\
\text { Tetewa'y managseg-ang nan Chios }\end{array}$ & $\begin{array}{l}\text { How great Thou art } \\
\text { How great Thou art }\end{array}$ & 1 \\
\hline 7 & $\begin{array}{l}\text { Layad omchan } \\
\text { Layad omchan }\end{array}$ & $\begin{array}{l}\text { When love shines in } \\
\text { When love shines in }\end{array}$ & 1 \\
\hline \multirow[t]{2}{*}{8} & At waday & $\begin{array}{l}\text { There will be } \\
\text { There will be a time }\end{array}$ & \multirow[t]{2}{*}{1} \\
\hline & At waday masab-atan tako & For us to meet once more & \\
\hline & TOTAL & & 7 \\
\hline
\end{tabular}

In sum, Table 13 summarizes the stylistic features that are applied in songs.

Table 13. Summary of Stylistic Features (Tropes and Schemes).

\begin{tabular}{cccc}
\hline & Stylistic Features & Frequency & Rank \\
\hline 1 & Neologism & 24 & 1 \\
2 & Imagery & 17 & 2 \\
3 & Repetition & 16 & 3 \\
4 & Simile & 14 & 4 \\
5 & Personification & 13 & 5 \\
6 & Rhetorical question & 9 & 6 \\
7 & Hyperbole & 7 & 7 \\
8 & Anaphora & 6 & 8 \\
9 & Metaphor & 5 & 9 \\
10 & Code-switching & 5 & 9 \\
\hline
\end{tabular}

In the framework of Prototype Theory, the prominent features of style in all of the songs collected from the songs of Tokwifi's Antoway, Bacwaden's Ayyoweng, and Khensay's Chag-ay are neologism, of which some deep Bontok words deal with other word formations where a newly adopted word changes its morphology to fit in the new language for musical purposes; imagery, repetition, and simile, where it is an important aspect in style that was prominently used in the song "Nan Talna...", with twelve simile used.

\subsection{The Prominent Songs}

From the survey, Table 14 reveals the songs that wereprominently sung during the days of the wake. 
Table 14. Examples of songs prominently sung during the wakes.

\begin{tabular}{|c|c|c|c|}
\hline Code No. & Songs Prominently Sung & Frequency & Rank \\
\hline 8 & $\begin{array}{l}\text { Mo Omchan nan Pachong } \\
\text { (When the Time Comes) }\end{array}$ & 56 & 1 \\
\hline 5 & $\begin{array}{l}\text { Manakabfalin } \\
\text { (How Great Thour Art) }\end{array}$ & 45 & 2 \\
\hline 2 & $\begin{array}{l}\text { Adik Taytaynan Sik-a } \\
\text { I'll Never Never Leave You }\end{array}$ & 39 & 3 \\
\hline 1 & $\begin{array}{l}\text { Nan Layad En Sikhafan } \\
\text { (Love Can Wrench a Pain So Deep) }\end{array}$ & 32 & 4 \\
\hline 6 & $\begin{array}{c}\text { Ayke ka Aped Apa-an ay Aped Tumaynan } \\
\text { (Are You Going Away with no Words of Farewell?) }\end{array}$ & 28 & 5 \\
\hline 7 & $\begin{array}{l}\text { Nalagsak Nan Am-in Mo Omchan nan layad } \\
\text { (When Love Shines In) }\end{array}$ & 17 & 6 \\
\hline 3 & $\begin{array}{l}\text { Nan Talna Ay Narpo Ken Chios Apo } \\
\text { (The Peace That My Savior has Given) }\end{array}$ & 11 & 7 \\
\hline 4 & $\begin{array}{l}\text { Iyayoweng Mi } \\
\text { (We Will Sing) }\end{array}$ & 5 & 8 \\
\hline 11 & $\begin{array}{l}\text { Waday Nan Esang ay Fab-alo } \\
\text { (There Was a Young man) }\end{array}$ & 2 & 9 \\
\hline 9 & $\begin{array}{l}\text { Nan Kasasaad taku Id kasin } \\
\text { (Our Fate Before) }\end{array}$ & 1 & 10 \\
\hline \multirow[t]{2}{*}{10} & $\begin{array}{l}\text { Nan Tet-ewa Nan Ifaknang } \\
\text { (The Truth of our Riches) }\end{array}$ & 0 & 0 \\
\hline & TOTAL & 236 & \\
\hline
\end{tabular}

When asked about the most requested and prominent songs during the wakes, Eugene Colian, 27 years old guitarist casually says:

"... during the past years, the songs are very much common for anybody can easily grasp the melody of the song immediately. Aside from that, the songs were adapted from a very popular gospel songs the reason why it is easy to follow and sing harmoniously". (interview by the researcher, Bontoc, Mountain Province, 15 November 2018).

Another interviewee Hydee Pachingel, 49 years old, proudly posits:

"For many years, I learned some of the songs from the book of Bacwaden in college several years ago. I learned to enjoy and appreciate her music, and that I acquire the skills to sing in tune and to have a keen rhythmic feeling for the beat. So whenever I joined community singing during wakes as my social obligation, I love the songs being sung especially how these songs were translated into our vernacular language. Like the song "Nan Layad Nen Sikhafan". (interview by the researcher, Bontoc, Mountain Province, 15 November 2018).

The data gathered through informal interviews imply that these respondents have knowledge of the selected songs from the collections of the Tokwifi group, Sofia Bacwaden, and Felix Khensay, respectively.

Helen Bagwan, 51 years old, another interviewee reasoned out her reactions when asked about the least chosen songs, like the song coded as four (4), 11, nine (9), and ten (10):

"Actually, there are songs included here in the books most especially on its vernacular lyrics; but the problem is, I don't know much of these songs. I used to hear these songs but to they were just only sung by few who do know these songs". (interview by the researcher, Bontoc, Mountain Province, 15 November 2018). 
As to the lyrics interpretation that was anchored in the framework of Relevance Theory, most of the interviewees do understand how the stylistic features were presented through their background knowledge of the tropes and schemes that were used by the composers. Since most of the mourners are not children, it is easier for them to be asked informally regarding the stylistic features construction that was used in the songs selected, because, in the Relevance Theory, it explains that those who are knowledgeable of the stylistic features used in the songs, they are expected to make utterances relevant enough to be worth processing. The greater the cognitive effect, the greater the relevance.

For the most loved songs that were written by Bacwaden, Requino, (a Tokwifi group composer) and Khensay, the respondents applied their knowledge to interpret the figurative languages that they have in that environment (context). The stylistic features that are commonly used are typical to the Bontok community, because the contents were drawn from the immediate setting. Therefore, the conclusion on the composers' styles is rich in figurative languages that reveal spirituality, love and relationships, and lamentations intended for easier interpretation, easier to memorize, and easier for community singing.

Most of the noted words from the songs were clipped and blended through the style of Neologism, because some of the melodies used for the songs composed were adapted from popular gospel songs that fit on the rhythm and musical measurement of the song.

In moving forward to the next millennium, the Bontoks must tend to carry these immortal songs through singing them in wakes and funerals carrying the messages that are embedded within them. The songs are the vocal portraits of the Bontok tribes, because they are the tunes of indigenous feeling emanating from the "Ifuntok's" heart.

\subsection{Notated Songs for Music Classroom Use}

When indigenous music is taught so that each new knowledge reveals new splendors, new adventures, new feelings, heartened, or conveyed, we may be sure that there will be conforming development in knowledge, skill, and power; or, we do well that which we love to do. We learn not so much by doing but mainly because we take pleasure in doing. Whether it be the more detailed study of rhythm, keys, modes, forms, or structure, or the mastery of part songs, the discovery of cultural or indigenous beauty should be the touchstone that quickens the activity with life and spirit.

In the Bontok culture, every song composed has played a momentous role in every celebration over the years. There were discussions brought out about the future of such indigenous songs popular to the Bontok society that they should be preserved for the next generations through notations, just like what Bacwaden did in her collections. One will understand that the songs that are composed by locals are the cultural foundation of every group of people. In this case, traditional Bontok songs were filtered through the cultural deeds of the Bontoks. The songs that were carried out in the society uphold togetherness and encourage the people's common spirit to serve as an avenue of hopeful participation in collective behaviour. Music in the Bontok community results in the spontaneous response to group needs and involvement in communal activity. It promotes members in the society, both near and far together as a way of increasing the social relationship that connects them and the moral principles that are desired in their corporate life.

From the informal interviews conducted, it was clear that, in the olden days, songs that were performed during wakes and funerals were done by the mourners in the community and the song texts were chosen depending on the life-style and nature of death of the deceased and the songs were simply plain texts only. In an earlier paper, "Indigenous Songs as an Instructional Aid in Teaching Mother Tongue to Pupils of Bontoc Central School: Its Educational Implications", [37] looked into the advantage and disadvantage of mass media from Western countries to the Bontoks that tendencies are, generations of today do not know some of these songs, unless the songs were to be notated for educational and performance use.

Therefore, Bacwaden's “Nan Layad en Sikhafan” from her Ayyoweng (see Figure 6) used as musical instructional material in today's curriculum in Bontoc, Mountain Province, where a complete 
understanding of the part that an indigenous song play in a people's literature requires a brief and general discussion of the song as a whole. Therefore, I will endeavor to present that the song was coined in a simple vernacular expression, which dealt with human passion, human needs, expressed in the light of human experience. Its simple rhyme, narrating a simple story, affords delightful music-a music for the soul-which sprung from the composer herself. Although this song is a simple one, I can find an unusual key and lyrical quality of a great "Ifuntok" beauty.

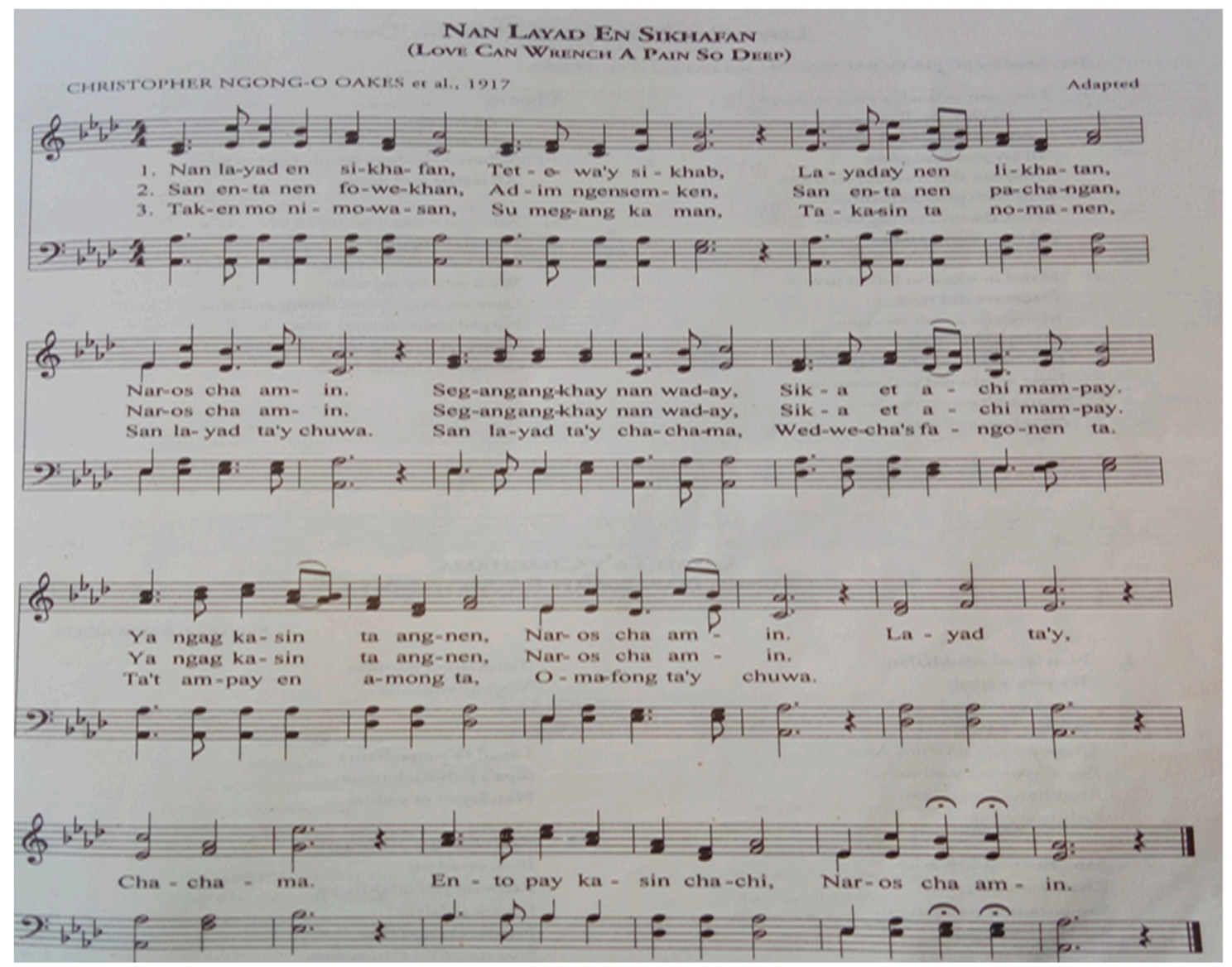

Figure 6. The song "Nan Layad Ensikhafan (Love Can Wrench a Pain So Deep)", a popular song included in Bacwaden's song book collection (photo by the researcher, 12 January 2018).

\section{Conclusions}

The songs that I collected from Tokwifi's Antoway, Bacwaden's Ayyoweng, and Khensay's Chag-ay are usually sung during wakes and funerals by the Bontoks that exposed the cultural, spiritual, and aesthetic values of the Bontok community. Additionally, it played a vital role in shaping the social and religious life of all the Ifuntoks. The songs have also revealed the themes in the social life of the Bontoks, which focused on spirituality, love and relationships, and lamentations. Furthermore, their lyrics are so powerful that it carries educational messages for instructional use.

Also in the selected songs, the most prominent stylistic features that are used by the composers are: neologism, imagery, repetition, simile and personification. I concluded that the interpretation of the songs selected depends on the stylistic features applied. Therefore, in the framework of Prototype Theory, the prominent features of style were mostly encountered in the songs that can be easily interpreted by the singers. These stylistic features attracted singers' attention depending on what stylistic features were used.

Lastly, these songs should be notated and integrated in today's music education, where teachers have to have techniques to make indigenous music meaningful, because, when music activity is 
centered in a meaningful, beautiful song, the appreciation of the beauty of the song, the joy of the experience and the feeling that the effort is worthwhile make learning delightful, sure, and lasting.

Funding: This research received no external funding.

Acknowledgments: The author would like to extend his sincere appreciation to the contributors to this paper and is grateful to the anonymous reviewers for their comments and suggestions, as well as editorial help to proofread my manuscript.

Conflicts of Interest: The author declares no conflict of interest.

\section{References}

1. Provincial Government of Mountain Province. The New Mountain Province; Zoom Printing Company: Quezon City, Philippines, 2010.

2. Vygotsky, L.S. Mind in Society: The Development of Higher Psychological Processes; Cole, M., John-Steiner, V., Scribner, S., Souberman, E., Eds.; Harvard University Press: Cambridge, MA, USA, 1978.

3. Wilson, D.; Sperber, D. Relevance Theory: Communication and Cognition; Blackwell: Oxford, UK, 1995.

4. Rosch, E. Principles of Categorization, 10th ed.; Earlbaum Associates: Hillsdale, MI, USA, 1973.

5. Furmanek, O. The Role of Emotions in Establishing Meaning: Implications for Interpreting. The Journal of Specialised Translation. 2006. Issue 5. Available online: http://www.jostrans.org/issue05/art_furmanek.php (accessed on 30 March 2018).

6. Aborampah, O.M. Women's roles in the mourning rituals of the Akan of Ghana. Univ. Pittsburgh Commonw. Syst. High. Educ. Stable 1999, 38, 257-271. Available online: http://www.jstor.org/stable/3773817 (accessed on 24 June 2018). [CrossRef]

7. Nketia, J. The Music of Africa; Norton: New York, NY, USA, 1974.

8. Saboy, S.M. Voicing ethnicity: Traditional referentiality, the ullalim, and kalinga ethnopop. In Journal of Philippine Culture and Society; Cordillera Studies Center: Baguio, Philippines, 2012; Volume IV, No. 2.

9. Fagsao, J. Traditional referentiality in Felix Khensay's literary contribution. Int. J. Sci. Manag. (IJSMS) 2019, $2,21-28$.

10. Fong, J.B. Batawa: Constructing Identity through Country Music in the Philippine Cordillera; Linkoping University Electronic Press: Linköping, Switzerland, 2007; Available online: www.ep.liu.se/ecp/025/013/ecp072513 (accessed on 24 June 2018).

11. Tokwifi. Antoway Tako; The Tokwifi Organization: Bontoc, Philippines, 2012.

12. Bacwaden, S. Ay-Yoweng (Tsinakhop); LGU Bontoc: Bontoc, Philippines, 2004.

13. Khensay, F. Chag-Ay Isnan Achog (Funeral Songs); Bontoc Scripture Society: Bontoc, Philippines, 1993.

14. Maceda, J. Chants from Sagada, Mountain Province. In Music Journal of the Philippines; Manlapaz Publishing Co.: Quezon City, Philippines, 1996; Volume 1, No. 1.

15. Regelski, T.A. Teaching General Music: Action Learning for Middle and Secondary Schools; Schirmer Books: New York, NY, USA, 1981.

16. Tait, M.; Haack, P. Principles and Processes of Music Education: New Perspectives; Teachers College Press, Columbia University: New York, NY, USA, 1984.

17. Egudu, R.N. The Content and Form of Yuruba Ijala; Longman Nigeria: Oxford, UK; Ikeja, Nigeria, 1981.

18. Amali, S.O.O. An Ancient Nigerian Drama: The Idoma Inquest; Franz Steiner: Stutgart, Germany, 1985.

19. Hananiya, J.P. The Kilba and Their Language; Lad Park Commercial Enterprises: Lagos, Nigeria, 1993.

20. Ogbe, N.G. Essential of Literature. A Comprehensive Approach to Literary Appreciation for Higher Education; Gab, Race, Optimal Ventures: Enugu, Nigeria, 1997.

21. Sakadolskis, E.A. The Use of Figurative Language in the Construction of Musical Meaning: A Case Study of Three Sixth Grade General Music Classes; University of Maryland at College Park: College Park, MD, USA, 2003.

22. Aklile, A. Stylistic Analysis of Selected Short Stories by Henry. Master's Thesis, Addis Ababa University, Addis Ababa, Ethiopia, 2015.

23. Mbuthia, M.; Mwangi, I. Analysis of stylistic trends in published Kiswahili short story genres. J. Educ. Pract. 2014, 5, 32-42.

24. Swanwick, K. Music making and music teaching as thoughtful action. In Music Education as Praxis: Reflecting on Music-Making as Human Action; McCarthy, M., Ed.; University of Maryland: College Park, MD, USA, 1999. 
25. Bakan, M.B. World Music: Traditions and Transformations, 2nd ed.; McGraw-Hill: New York, NY, USA, 2012.

26. Cross, I. Music and biocultural evolution. In The Cultural Study of Music: A Critical Introduction; Trevor Herbert and Richard Middleton, 24-25; Martin, C., Ed.; Routledge: London, UK, 2003.

27. Fiar-od, C.B. Besao Traditional Knowledge on Spiritual Beliefs. It's Contribution to Sustainable Development; Mountain Province State Polytechnic College: Bontoc, Philippines, 1999.

28. Quinn, E. A Dictionary of Literary and Thematic Terms; Facts on File, Inc.: New York, NY, USA, 1999.

29. Cuddon, J.A. The Penguin Dictionary of Literary Terms and Literary Theory, 4th ed.; Preston, C.E., Ed.; Penguin: Harmondsworth, UK, 1998.

30. Khaoya, G. Form and Content of "Chisw" Harvesting Songs in Bukusu Community. Master's Thesis, The University of Nairobi, Nairobi, Kenya, 2013.

31. Shogren, J. Analysis of Code-Switching and Code-Mixing Among Bilingual Children: Two Case Studies of Serbian-English Language Interaction; Wichita State University: Wichita, KS, USA, 2011.

32. Gardner-Chloros, P. Code-Switching; Cambridge Press: Cambridge, MA, USA, 2009.

33. Larson, M.L. Meaning-Based Translation; University Press of America Inc.: Lanham, MD, USA, 1998.

34. Kemertelidze, N.; Manjavidze, T. Stylistic repetition, its peculiarities and types in modern English. Special Edition. Eur. Sci. J. 2013, 9, 4.

35. Drout, M.D.C. A meme-based approach on oral tradition theory. Oral Tradit. 2006, 21, 283.

36. Foley, J.M. Immanent Art: From Structure to Meaning in Traditional Oral Epic; Indiana University Press: Bloomington, IN, USA, 1991.

37. Fagsao, J. Indigenous songs as an instructional aid in teaching mother tongue to pupils of Bontoc central school: Its educational implications. Int. J. Sci. Manag. Stud. (IJSMS) 2019, 2, 103-111, ISSN: 2581-5946.

(C) 2019 by the author. Licensee MDPI, Basel, Switzerland. This article is an open access article distributed under the terms and conditions of the Creative Commons Attribution (CC BY) license (http://creativecommons.org/licenses/by/4.0/). 